\title{
The State Supports in International Competition and Their Importance: Case of Turkey
}

\author{
Mehmet Burak Ceran \\ Selcuk University, Konya ,Turkey
}

\begin{abstract}
In the global competitive environment, the commercial boundaries between enterprises have been disappeared with the agreements made between countries and developing internet technology. In today's economy, where the dimensions of competition become more difficult each day, it is possible for businesses to survive and compete with their competitors on international platforms, to provide the necessary transformations for competition within the enterprise and to adapt the business processes to today's competitive conditions. However, as a result of the developments in international competition and the fact that the world has become an open market, it is necessary to support the enterprises with different support programs in their countries. Providing state subsidies to exporting enterprises, foreign trade has a strategic importance especially for the countries has an important role. In order to be able to compete with its competitors in the global competitive environment, exporting enterprises which have a position to gain foreign currency and thus develop the country's economy should support these enterprises as a state policy. In the study, referring to the importance of government support in ensuring the success of businesses in the international competitive exporter of government support given to enterprises in Turkey will be discussed.
\end{abstract}

Keywords: international trade, supporting programmes, competition, export, competitive advantage 